\title{
Effects of Knowledge Management and Strategic Improvisation on SME Performance in Malaysia
}

\author{
Hatinah Abu Bakar ${ }^{1}$, Rosli Mahmood ${ }^{2} \&$ Nik Nor Hasimah Ismail ${ }^{3}$ \\ ${ }^{1}$ Othman Yeop Abdullah Graduate School of Business, Universiti Utara Malaysia, Sintok, Kedah, Malaysia \\ ${ }^{2}$ School of Business Management, College of Business, Universiti Utara Malaysia, Sintok, Kedah, Malaysia \\ ${ }^{3}$ Faculty of Business, Universiti Teknologi MARA Kelantan, Machang, Kelantan, Malaysia \\ Correspondence: Rosli Mahmood, School of Business Management, College of Business, Universiti Utara \\ Malaysia, 06010 Sintok, Kedah, Malaysia. Tel: 60-49-28-7495. E-mail: rosli@uum.edu.my
}

Received: October 29, 2014

Accepted: December 15, 2014 Online Published: April 2, 2015

doi:10.5539/ass.v11n9p207

URL: http://dx.doi.org/10.5539/ass.v11n9p207

\begin{abstract}
This research aims to determine the relationship between knowledge management (KM) and strategic improvisation with performance of small-medium enterprises (SMEs). The research employs a quantitative mail survey method and data were collected randomly from the owner/managers of registered SMEs. A total of 131 usable responses were received. Partial Least Square (PLS) modelling was used to estimate the hypothesized research model. Significant relationship was found to exist between KM and performance, and also between strategic improvisation and performance.
\end{abstract}

Keywords: small and medium enterprises, knowledge management, strategic improvisation, performance

\section{Introduction}

Small and medium enterprises (SMEs) are crucial to the economic development of most nations. A strong SME sector stimulates an upward mobility of an economy with the creation of job opportunities and innovation promotions (Herath \& Mahmood, 2014). However, SMEs also face many constraints such as technological backwardness, shortage of entrepreneurial competencies, capabilities and skills among the key management, insufficient use of information technology and poor product quality (Emine, 2012). In Malaysia SMEs constitute 99 percent of the total business establishments, contribute 32.5 percent of gross domestic product (GDP), and 59 percent of employment (Singh \& Mahmood, 2014). However, low level of performance is one of the key issues affecting the sector. Thus SMEs need to be more resilient in this globalized business environment where competitive rivalry has multiplied in its magnitude. These include the need for SMEs to refigure their strategic orientation in the form of knowledge management and strategic improvisation in order to benefit from the rapid change and to gain and maintain competitive advantage. Therefore the objective of this study is to investigate the effects of knowledge management and strategic improvisation on the performance of SMEs.

\section{Literature Review}

\subsection{Knowledge Management and Firm Performance}

Knowledge management (KM) has been increasingly recognized as an important tool for sustaining competitive advantage and improving performance. According to Rastogi (2000) and Lawson (2003), KM is a process in integrating and coordinating systematically the acquisition, creation, and deployment of knowledge, experience and expertise in an organization. The process involves systematic analyses, planning, acquisition, creation, development, storage and use of knowledge to achieve organisational goals (Omerzel, 2010; Suzana \& Kasim, 2010). An effective KM strategy will lead to lesser time in the process of information and reuse of knowledge because it enhances the creation, transfer and utilisation of knowledge in the organisation (Alavi, 2000). The process of creating, sustaining and renewing in $\mathrm{KM}$ usually results in value creation and improvement in organisational performance (Allee, 2003).

Past studies have examined the relationship between knowledge management and firm performance. McKeen et al (2006) found significant positive links between high adoption of KM practices and high performance while Liao and Chuang (2006) concluded that KM resources have positive influence on KM process capabilities which, 
in turn positively influences firm performance. Chuang (2004) who empirically examined the association between KM capabilities and competitive advantage found evidence that KM has a significant impact on competitive advantage. Hsu (2006) also established that KM process capability lead to superior firm performance. Kridan and Goulding (2006) found the significance of KM for enhancing the organizations' performance and that led them to better position, and the study by Lee, Kim and Kim (2012) demonstrated the relevance of KM infrastructure for organizational performance.

Gloet and Terziovsky (2004) who explored the relationship between KM practices and innovation performance found that the humanistic approach to KM was significantly and positively related to innovation performance whereas the technology based KM and innovation performance was negatively related. Mills and Smith (2011) did a study on KM and organizational performance: a decomposed view using the survey method to evaluate the impact of specific KM resources on organizational performance in Jamaica. It was found that some knowledge resources such as organizational structure and knowledge application are directly related to performance, while others, such as technology and knowledge conversion, are not. However, Kongpichayanond (2013) found support that KM enhanced innovation performance directly, and also indirectly associated with innovation performance through a mediator, Total Quality Management. Nonetheless, Zaim et al. (2007) indicated that even though a significant relationship was found between KM and performance, the result could not be generalized to a wider population. Similarly Zack et al (2009) argued that the results based on North American and Australian companies could not be generalized to other geographic, economic and culture. Thus it is hypothesized that:

H1: There is significant and positive relationship between knowledge management and SME performance.

\subsection{Strategic Improvisation and Performance}

Organisations which are struggling to continuously adapt and survive in today's rapidly changing environment are turning to an emerging technique known as improvisation. According to McKnight and Bontis (2002) improvisation is the "ability to spontaneously recombine knowledge, processes and structure in real time, resulting in creative problem solving that is grounded in the realities of the moment". The spontaneous action is resulted not through a deliberate process of thought and evaluation but on the spur of moment based on the intuition guiding the way (Crossan \& Sorrenti, 2002; Ciborra, 1999; Moorman \& Miner, 1998).

Strategic improvisation is the best strategy to cope with the rapid changes in environmental demands because it provides the organization with flexibility and capabilities. Organisations which do not have 'time' to plan may found improvisation useful as a strategy (Baker \& Nelson, 2005; Kamoche et al., 2003). Improvisation is also seen as a new paradigm for organisation's strategic choice (Eisenhardt, 1997), strategic performance construct (Moorman \& Miner, 1998), emergent learning (Mintzberg, 1994), and strategic renewal (Vera \& Crossan, 2005).

Few studies have investigated the direct effect of improvisation on firm performance (Arshad \& Hughes, 2009; Arshad, 2011). Most of other studies only examined indirect correlation between improvisation and performance through some moderating factors (Vera \& Crossan, 2005), or focused on new product success teams and new product development as the main performance measures (Akgun, Lynn, \& Byrne, 2006; Leybourne \& Sadler-Smith, 2006; Vera \& Crossan, 2005; Akgun \& Lynn, 2002). Leybourne and Sadler-Smith (2006) found no significant relationship between improvisation and satisfactory project outcomes, while Akgün et al. (2006) indicated the impact of improvisation on new product success. Other studies included Hmieleski and Corbett (2008) who focused on the relationship between improvisation behaviour of firm founders with performance, and Hmieleski, Corbett and Baron (2013) on improvisational behavior of entrepreneurs and performance, and who investigated the direct impact of improvisation on firm performance. Nonetheless, there is still a paucity of studies that examine the direct relationship between strategic improvisation and firm performance as a whole. Thus the following hypothesis:

$\mathrm{H} 2$ : There is significant and positive relationship between strategic improvisation and performance of SMEs in Malaysia.

\section{Research Methodology}

The sample for the study comprised of owner/managers from the SMEs in Malaysia. Owner/managers were targeted because they are the key informants of the business and usually they are involved in the overall running of the firms. In addition, the views of the owner/managers often represent the views of the entire firms. A total of 131 useable questionnaires were collected from the respondents.

The questionnaires were developed using established measures from previous studies. The knowledge management measure was adapted from Rasula, Vuksic and Stemberger (2012). It consisted of nine items which include questions on accumulation, utilization, sharing practices and knowledge ownership identification. The 
strategic improvisation of seven items was measured using scales adapted from Vera and Cossan (2005). The items were measured on a five-point Likert scales where ' 5 ' represents strongly agree, and ' 1 ' represents strongly disagree. For measuring performance, a subjective self-report assessment was used. This technique was employed because it was expected that the owner/managers would be unwilling to disclose full financial data. This study measured performance with eight items, and the respondents were asked to rate their firm performance on a five-point rating scale. It has been found that subjective measures are correlated with the objective measures of performance (Dess \& Robinson, 1984).

Descriptive statistical analysis was performed using SPSS for Windows 18.0 to analyze the nature of the data and to develop a profile of respondents. Partial Least Square (PLS) path modeling was used to analyse the relationships between knowledge management and performance, and between strategic improvisation and performance. PLS was used because it is capable of maximizing the explained variance in the dependent variable. In addition PLS does not require normality of the data distribution, and also does not demand specified minimum sample size (Hair et al., 2014).

\section{Results}

\subsection{Demographic Profile}

Table 1 shows that the number of male respondents is slightly higher than the female respondents with 71 $(54.2 \%)$ and $60(45.8 \%)$ respectively. Majority of the respondents (63 or 48.1\%) either held Sijil Pelajaran Malaysia (SPM) or Sijil Tinggi Pelajaran Malaysia (STPM) qualifications while another 32 respondents (22.4\%) obtained their Diplomas and $29(22.1 \%)$ with First degree qualification. Three respondents held post degree qualifications with two who obtained Master degree and one a $\mathrm{PhD}$ holder. In terms of years in operation, 66 (50.4\%) of the respondents' firms have been established between 5-10 years and $46(35.1 \%)$ have been in operation in less than 5 years. Another $11(8.4 \%)$ percent of the respondents' firms were established between 11-15 years. Only 4 (3.1\%) firms have been in existence for more than 20 years. With regard to number of employees, 55.4 percent of the firms have less than 5 workers, 42 percent have between 5-50 workers, and four (3.0\%) firms have between 51-150 workers.

Table 1. Profile of respondents

\begin{tabular}{|c|c|c|}
\hline Characteristics & Frequency & Percentage \\
\hline \multicolumn{3}{|l|}{ Gender } \\
\hline Male & 71 & 54.2 \\
\hline Female & 60 & 45.8 \\
\hline \multicolumn{3}{|l|}{ Education } \\
\hline $\mathrm{PhD}$ & 1 & 8.0 \\
\hline Master & 2 & 1.5 \\
\hline Bachelor & 29 & 22.1 \\
\hline Diploma & 32 & 22.4 \\
\hline SPM/ STPM & 63 & 48.1 \\
\hline Others & 4 & 3.1 \\
\hline \multicolumn{3}{|l|}{ Years in Operation } \\
\hline Less than 5 years & 46 & 35.1 \\
\hline $5-10$ years & 66 & 50.4 \\
\hline $11-15$ years & 11 & 8.4 \\
\hline $16-20$ years & 4 & 3.1 \\
\hline More than 20 years & 4 & 3.1 \\
\hline \multicolumn{3}{|c|}{ Number of employees } \\
\hline Less than 5 employees & 72 & 55.4 \\
\hline $5-50$ & 55 & 42.0 \\
\hline $51-150$ & 4 & 3.0 \\
\hline
\end{tabular}

\subsection{Construct Validity}

The construct validity is the extent to which a set of items in an instrument represents the construct to be measured. If the measurement model shows an acceptable level of model fit, then it is an evidence for the availability of construct validity (Hair et al., 2014). The validity of the measurement model was assessed by testing the convergent validity and discriminant validity. The convergent validity exists when the indicators of 
one construct converge or share a higher proportion of variance. The violation of the convergent validity adversely affects the findings. The convergent validity in the model was established by calculating the factor loadings, the average variance extracted (AVE) and composite reliability (CR) for all constructs. Hair et al., (2010) suggested the cut off value for loadings at a minimum of 0.5 as significant. All loadings in this study which are greater than 0.5 and the high values of the CR and AVE indicate the presence of convergent validity (See Table 2).

Table 2. Results of convergent validity analysis

\begin{tabular}{|c|c|c|c|c|}
\hline Construct & Item & Loading & $\mathrm{CR}$ & AVE \\
\hline \multirow{5}{*}{ Performance (FP) } & FP1 & 0.897 & \multirow{5}{*}{0912} & \multirow{5}{*}{0.776} \\
\hline & FP2 & 0.901 & & \\
\hline & FP3 & 0.843 & & \\
\hline & KM1 & 0.799 & & \\
\hline & KM2 & 0.782 & & \\
\hline \multirow{5}{*}{ Knowledge Management } & KM3 & 0.698 & \multirow{5}{*}{0.909} & \multirow{5}{*}{0.527} \\
\hline & KM4 & 0.588 & & \\
\hline & KM5 & 0.735 & & \\
\hline & KM6 & 0.762 & & \\
\hline & KM7 & 0.705 & & \\
\hline \multirow{9}{*}{ Strategic Improvisation (SI) } & KM8 & 0.715 & \multirow{9}{*}{0.900} & \multirow{9}{*}{0.564} \\
\hline & KM9 & 0.727 & & \\
\hline & SI1 & 0.811 & & \\
\hline & $\mathrm{SI} 2$ & 0.723 & & \\
\hline & SI3 & 0.818 & & \\
\hline & SI4 & 0.718 & & \\
\hline & SI5 & 0.772 & & \\
\hline & SI6 & 0.692 & & \\
\hline & SI7 & 0.713 & & \\
\hline
\end{tabular}

Discriminant validity is the extent to which a construct is different from other constructs (Hair et al., 2010). Establishing discriminant validity implies that a construct is unique and that the set of items measuring a construct is distinct from another set of items measuring other constructs. In examining discriminant validity the Fornell and Larker (1981) criterion was used. It compares the square root of the AVE values with the construct correlations, and that each construct's AVE should be higher than construct's highest squared correlation with other construct. Table 3 shows the correlation matrix where the diagonal figures represent the square root of the VE extracted of the constructs. The test results indicate that there is adequate discriminant validity since the diagonal elements are significantly greater than the off-diagonal elements in the corresponding rows and columns.

Table 3. Results of discriminant validity analysis

\begin{tabular}{llll}
\hline & EO & FP & SI \\
\hline Firm Performance (FP) & $\mathbf{0 . 8 8 1}$ & & \\
Knowledge Management & 0.474 & $\mathbf{0 . 7 2 6}$ & $\mathbf{0 . 7 5 1}$ \\
Strategic Improvisation (SI) & 0.519 & 0.684 & \\
\hline
\end{tabular}

Note: Values in the diagonal (bold) are square root of the AVE while the off diagonals are the inter construct correlations.

\subsection{Hypotheses Tests}

Partial Least Squares (PLS) analysis was used to generate a structural model and then to conduct the hypotheses testing. The path coefficients generated by PLS provide an indication of the relationships and can be used similar to the traditional regression coefficients (Gefen, Straub, \& Boudreau, 2000). Path coefficients indicate the strengths of the relationships between the independent and dependent variables, and a significant path indicates that the relationships and hypotheses are empirically supported. Meanwhile $\mathrm{R}^{2}$ value is a measure of the predictive power of a model for the dependent variable, and the larger the value is, the larger the percentage of variance explained. T-values of the parameter indicate the strength of the relationship the parameter represents, 
and the higher the t-value, the stronger the relationship is. The bootstrapping procedure using 5000 sample was used to obtain the t-values of each coefficient (Chin, 2010; Efron \& Tibshirani, 1993). Results of the analysis are depicted in Figure 2.

Path analysis was used to test the two hypotheses generated from the research model. The $\mathrm{R}^{2}$ for this model is 0.296 , meaning that only 29.6 percent of the variance can be explained in the extent of knowledge management and strategic improvisation. Based on path coefficient and t-test value results show that $\mathrm{H} 1$ and $\mathrm{H} 2$ are supported. The results show that knowledge management (KM) and strategic improvisation (SI) positively influence the SME performance at significant level of $\mathrm{p}<0.05$ (See Table 4).

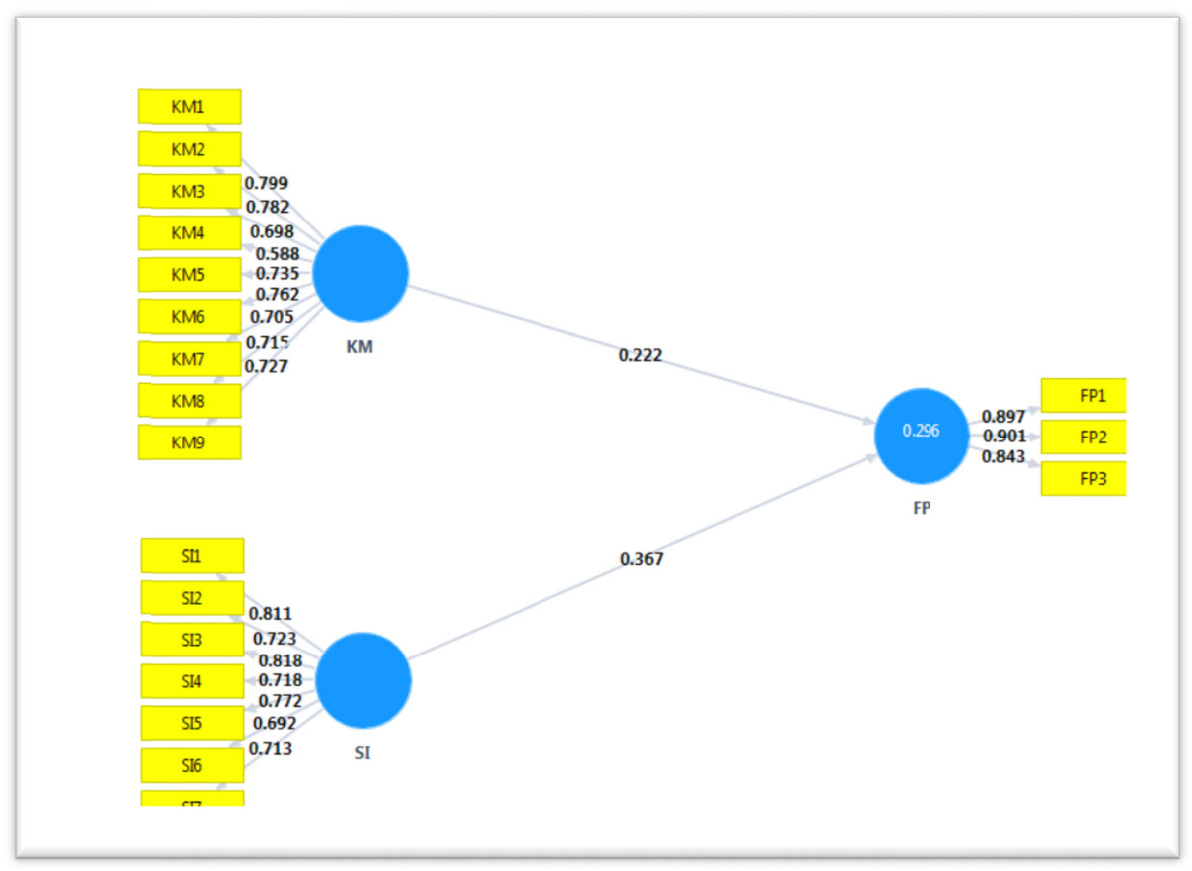

Figure 2. Results of path analysis

Table 4. Path coefficient and Hypotheses testing

\begin{tabular}{llllll}
\hline Hypothesis & Relationship & Std. Beta & Std. Error & t-value & Decision \\
\hline H1 & KM $>$ FP & 0.222 & 0.110 & $2.027^{*}$ & Supported \\
H2 & SI $>$ FP & 0.367 & 0.112 & $3.287^{*}$ & Supported \\
\hline
\end{tabular}

*Significance at $p<0.05$

\section{Conclusions}

This study investigated the effects of knowledge management and strategic improvisation on performance of SMEs in Malaysia. Result of the analysis shows significant positive relationship between knowledge management and performance. Thus it can be included that knowledge management practices are critical elements for improvement in the performance of SMEs. This finding can be used to improve the knowledge management practices among the SMEs in the time of rapid change in the environment. SMEs should employ these KM practices that is acquiring, creating, storing, sharing, implementing and disseminating knowledge in order to make strategic decisions that can lead to improved performance and sustain competitive advantage.

The findings also demonstrate that strategic improvisation does contribute to an increased performance. Strategic improvisation which constitutes spontaneity, creativity and intuition, is even necessary in situations that require immediate corrective actions where most of the SMEs are in. Improvisation may increase the flexibility and adaptability of the SMEs in those situations. In addition it can be a source of competitive advantage because creativity and intuition in strategic decision making affects performance in changing business environments. Thus to succeed SMEs need to foster more strategic improvisational actions that can bring out change, enhance operational efficiency, and contribute to organizational performance and competitive advantage. 


\section{References}

Akgun, A. E., \& Lynn, G. S. (2002). New product development team improvisation and speed-to-market: An extended model. European Journal of Innovation Management, 5(3), 117-129. http://dx.doi.org/10.1108/ 14601060210436709

Akgun, A. E., Lynn, G. S., \& Byrne, J. C. (2006). Antecedents and consequences of unlearning in new product development teams. Journal of Product Innovation Manufacturing, 23, 73-88. http://dx.doi.org/10.1111/ j.1540-5885.2005.00182.x

Alavi, M. (2000). Managing organizational knowledge. In R. W. Zmud (Ed.), Framing the domains of IT management projecting the future...through the past (pp. 15-28). OH: Pinnaflex Education.

Allee, V. (2003). The future of knowledge: Increasing prosperity through value networks. Burlington, MA: Elsevier Science.

Arshad, D. A. (2011). Understanding organizational improvisation: foundations and performance implications (Unpublished $\mathrm{PhD}$ thesis). Loughborough University, UK.

Arshad, D. A., \& Hughes, P. (2009). Examining organizational improvisation: The role of strategic reasoning and managerial factors. World Academy of Science, Engineering and Technology, 54, 548-554.

Baker, T., \& Nelson, R. E. (2005). Creating something from nothing: resource construction through entrepreneurial bricolage. Administrative Science Quarterly, 50, 329-366. http://dx.doi.org/10.2189/ asqu.2005.50.3.329

Chin, W. W. (2010). How to write up and report PLS analyses. In V. E. Vinzi, W. W. Chin, J. Henseler, \& H.Wang (Eds.), Handbook of partial least squares. Berlin: Springer-Verlag. http://dx.doi.org/10.1007/ 978-3-540-32827-8_29

Chuang, S. (2004). A resource-based perspective on knowledge management capability and competitive advantage: An empirical investigation. Expert Systems with Application, 27(3), 459-465. http://dx.doi.org/10.1016/j.eswa.2004.05.008

Ciborra, C. U. (1999). Notes on improvisation and time in organizations. Accounting, Management and Information Technology, 9(2), 77-94. http://dx.doi.org/10.1016/S0959-8022(99)00002-8

Crossan, M., \& Sorrenti, M. (2002). Organizational improvisation. London: Routledge.

Dess, G. G., \& Robinson, R. B. (1984). Measuring organizational performance in the absence of objective measures: The case of privately-held firm and conglomerate business unit. Strategic Management Journal, 26, 1249-1259.

Efron, B., \& Tibshirani, R. (1993). An introduction to the bootstrap. Boca Raton, FL: Chapman and Hall. http://dx.doi.org/10.1007/978-1-4899-4541-9

Eisenhardt, K. M. (1997). Strategic decision and all that jazz. Business Strategy Review, 8(3), 1-3. http://dx.doi.org/10.1111/1467-8616.00031

Emine, D. (2012). Financial challenges that impede increasing the productivity of SMEs in the Arab region. Journal of Contemporary Management, 1, 17-32.

Fornell, C., \& Larker, D. F. (1981). Evaluating structural equation models with unobservable variables and measurement error. Journal of Marketing Research, 18(1), 39-50. http://dx.doi.org/10.2307/3151312

Gefen, D., Straub, D. W., \& Boudreau, M. C. (2000). Structural equation modeling and regression: guidelines for research practice. Communication of the Association for Information Systems, 4(7), 1-79.

Gloet, M., \& Terziovski, M. (2004). Exploring the relationship between knowledge management practices and innovation performance. Journal of Manufacturing Technology Management, 15(5), 402-409. http://dx.doi.org/10.1108/17410380410540390

Hair, J. F., Black, W. C., Babin, B. J., \& Anderson, R. E. (2010). Multivariate data analysis. New Jersey: Prentice Hall.

Hair, J., Hult, T. M., Ringle, C. M., \& Sarstedt, M. (2014). A primer on partial least squares structural equation modeling. Thousand Oaks: Sage.

Herath, H. M. A., \& Mahmood, R. (2014). Determining a model of SME performance based on the dimensions of entrepreneurial orientation and absorptive capacity of the firm. Annual Conference on Management and 
Social Sciences, Singapore, August 15 -17.

Hmieleski, K. M., \& Corbett, A. C. (2008). The contrasting interaction effects of improvisational behavior with entrepreneurial self-efficacy on new venture performance and entrepreneur worj satisfaction. Journal of Business Venturing, 23(4), 482-496. http://dx.doi.org/10.1016/j.jbusvent.2007.04.002

Hmieleski, K. M., Corbett, A. C., \& Baron, R. A. (2013). Entrepreneurs' improvisational behavior and firm performance: A study of dispositional and environmental moderators. Strategic Entrepreneurship Journal, 7(2), 138-150. http://dx.doi.org/10.1002/sej.1143

Hsu, H. Y. (2006). Knowledge management and intellectual capital (Unpublished PhD dissertation). Southern Illinois University, Carbondale, IL, US.

Kamoche, K., Cunha, M. P., \& Cunha, J. V. (2003). Towards a theory of organizational improvisation: Looking beyond the Jazz Metaphor. Journal of Management Studies, 40(8), 2023-2051. http://dx.doi.org/10.1046/ j.1467-6486.2003.00410.x

Kongpichayanond, P. (2013). Perceived relationships among knowledge management, TQM and organization innovation performance: A Thai study (Unpublished PhD dissertation). University of Minnesota, US.

Kridan, A. B., \& Goulding, J. S. (2006). A case study on knowledge management implementation in the banking sector. Journal of Information and Knowledge Management Systems, 36(2), 211-222. http://dx.doi.org/10.1108/03055720610683013

Lawson, S. (2003). Examining the relationship between organizational culture and knowledge management. (Unpublished doctoral dissertation). Nova Southern University.

Lee, S., Kim, B. G., \& Kim, H. (2012). An integrated view of knowledge management for performance. Journal of Knowledge Management, 16(2), 183-203. http://dx.doi.org/10.1108/13673271211218807

Leybourne, S., \& Sadler-Smith, E. (2006). The role of intuition and improvisation in project management. International Journal of Project Management, 24(6), 483-492. http://dx.doi.org/10.1016/j.ijproman.2006. 03.007

Liao, C., \& Chuang, S. H. (2006). Exploring the role of knowledge management for enhancing firm's innovation and performance. Proceedings of the Hawaiian International Conference on System Sciences, Hawaii, January.

McKeen, J. D., Zack, M. H., \& Singh, S. (2006). Knowledge management and organizational performance: An exploratory study. Proceedings of the Hawaiian International Conference on System Sciences, Hawaii, January.

McKnight, B., \& Bontis, N. (2002). E-improvisation: collaborative groupware technology expands the reach and effectiveness of organizational improvisation. Knowledge and Process Management, 9(4), 219-227. http://dx.doi.org/10.1002/kpm.154

Mills, A. M., \& Smith, T. A. (2011). Knowledge management and organizational performance: a decomposed view. Journal of Knowledge Management, 15(1), 156-171. http://dx.doi.org/10.1108/136732711111108756

Mintzberg, H. (1994). Rise and fall of strategic planning. New York: The Free Press.

Moorman, C., \& Miner, A. S. (1998). The convergence between planning and execution: improvisation in new product development. Journal of Marketing, 62(3), 1-20. http://dx.doi.org/10.2307/1251740

Omerzel, D. G. (2010). The impact of knowledge management on SME growth and profitability: A structural equation modeling study. African Journal of Business Management, 4(16), 3417-3432.

Rastogi, P. N. (2000). Knowledge management and intellectual capital: The new virtuous reality of competitiveness. Human Systems Management, 19(1), 39-49.

Rasula, J., Vuksic, V. B., \& Stemberger, M. I. (2012). The impact of knowledge management on organizational performance. Economic and Business Review, 14(2), 147-168.

Singh, H., \& Mahmood, R. (2014). Cobined effect of competitive and manufacturing strategies on export performance of SMEs in Malaysia. Global Journal of Management and Business Research, 14(1), 99-106.

Suzana, R., \& Kasim, R. (2010). The relationship of knowledge management practices, competrencies and the organizational performance of government departments in Malaysia. International Journal of Human and Social Sciences, 5(4), 219-225. 
Vera, D., \& Crossan, M. (2005). Improvisation and innovative performance in teams. Organisation Science, 16(3), 203-224. http://dx.doi.org/10.1287/orsc.1050.0126

Zack, M., McKeen, J., \& Singh, S. (2009). Knowledge management and organizational performance: an exploratory analysis. Journal of Knowledge Management, 13(6), 392-409. http://dx.doi.org/10.1108/ 13673270910997088

Zaim, H., Tatoglu, E., \& Zaim, S. (2007). Performance of knowledge management practices: A causal analysis. Journal of Knowledge Management, 11(6), 54-67. http://dx.doi.org/10.1108/13673270710832163

\section{Copyrights}

Copyright for this article is retained by the author(s), with first publication rights granted to the journal.

This is an open-access article distributed under the terms and conditions of the Creative Commons Attribution license (http://creativecommons.org/licenses/by/3.0/). 